\title{
Beliefs and Actions of University Lecturers of Sports Sciences and Physical Activity Regarding Students' Learning Motivation
}

\author{
Noelia Melero Aguilar ${ }^{1}$, Ana Domenech Vidal'², Ruth Cabeza-Ruiz ${ }^{3}$ \\ 1 Noelia Melero Aguilar, University of Seville, Departament of Theory and History of Education and Social \\ Pedagogy, C/ Pirotecnia s/n, ES-41013, Seville, Spain, nmelero@us.es \\ 2 Ana Domenech Vidal, University of Cadiz, Department of Didactics, C/ República Saharaui, 12, ES-11519, \\ Puerto Real, Cádiz, Spain, ana.domenech@gm.uca.es \\ 3 Ruth Cabeza-Ruiz, University of Seville, Department of Human performance and Sport, C/ Pirotecnia s/n, \\ ES-41013, Seville, Spain, ruthcr@us.es
}

\begin{abstract}
This article presents a study on the perceptions of university professors of Physical Activity and Sport Sciences about the causes of lack of learning motivation of students with and without disabilities and the actions they take to motivate them. 16 semi-structured interviews were analyzed in an inductive manner. The results suggest that university teachers value students, enable positive learning environments, and address the interests and needs of all students through inclusive curricular practices.
\end{abstract}

Keywords: inclusive pedagogy, sports sciences, physical activity, university lecturers, motivation.

\section{Introduction}

Inclusion in education has been widely known for several decades (UNESCO, 1994; Tant and Watelane, 2016). In the Spanish context, inclusion is applied mainly in primary and secondary educational centres, largely influenced by governmental policies that promote it (Spanish Government, 2006 and 2013). However, and despite the current regulations, it seems that this sensitivity and predisposition toward inclusion is lost in the levels of higher education. In this sense, the emerging needs and the demands of the university community itself have produced some modifications related to policies and 
regulations toward a more egalitarian and inclusive perspective (Jucevičienė, Vizgirdaite, Alexander, 2018). In the year 2007, a law of universities was enacted (Spanish Government, 2006), based on the principles of equality. This law established the obligation to guarantee that university environments had the means, support and resources to ensure equal opportunities for all students.

Nowadays, the population of students attended to in universities is more and more diverse. In this sense, attention to diversity cannot involve only students with disabilities (Vlachou, 2004). The idea of diversity must not be limited to specific groups; it must be understood as the heterogeneity of the students, regardless of their ethnicity, sexual orientation or ability. Therefore, university lecturers face the challenge of giving an adequate response to student groups whose previous experiences, social situation and personal characteristics condition their commitment and participation in the classroom (Hockings, 2007).

This article is part o a larger project funded by the Spanish Ministry of Economy and Competitiveness entitled "Inclusive Pedagogy in the University: Teachers' Narratives" (EDU2016-76587-R). This project is carried out by a team of researchers from different fields of knowledge (Education Sciences, Economic Sciences, Health Sciences and Experimental Sciences) and from different Spanish universities. The aim of this research is to know the beliefs, knowledge, designs and actions that university lecturers apply to carry out an inclusive pedagogy.

In this sense, there is lack of research that focuses on analysing what good inclusive practices are in Higher Education, what strategies are used for the real inclusion of students at university environment and what characteristics present inclusive university professors. Therefore, in this study, participants were selected as 'inclusive teachers' by university students with disabilities. In this way, it was possible to know what is the perception of those teachers who develop inclusive practices in university classrooms. Specifically, in this study we focused on the beliefs and actions of these university lecturers. In both dimensions, one of the fundamental aspects was the motivation of all students, in general, and the motivation of students with disabilities, in particular. Therefore, the objectives of this work were: i) to analyse the beliefs of university lecturers with respect to the discouragement of university students, and ii) to know the actions that they carry out to motivate these students.

\section{Theoretical Background}

The concepts of inclusion and attention to diversity have been developed and discussed since several decades ago. In fact, although this approach emerged from special education (Florian, 2014), its theoretical, political and practical evolution make it a fundamental element for the education of all students. 
Education is facing a constant transformation since inclusion is conceived as a socalled "never-ended" process. The aim is to foster the participation of all students and reduce the cultural and educational exclusion of some of them (Muthukrishna, 2002). To sum up, inclusion is an ideology that defends that every person can participate in the teaching-learning process (Whitburn \& Plows, 2017). This new regulatory and pedagogical approach brings universities to a different level, from which they must create environments for everyone. These environments must allow and value students' differences and adopt the principle of equality as a fundamental principle (Ainscow, Dyson, Goldrick \& West, 2013).

Thus, we can assert that the education system itself is facing a challenge based on "complex pedagogical effort" (Florian \& Black-Hawkins, 2011). In order to carry out inclusive pedagogy, this must apply to everyone, which usually is effective for few, with the aim of generalising participation in the classroom, without differentiation (BlackHawkins, 2017). Curricular practices, evaluation and teaching methods linked to an inclusive pedagogy have the potential to satisfy and attend to the needs of all students (Barrington, 2004). Consequently, it generates significant, useful and accessible learning for everyone (Hockings, 2010).

According to Gale and Mills (2013), inclusive pedagogy is based on three principles: i) the belief that all students contribute to the learning environment, ii) the design of a pedagogy that values differences, and iii) the development of actions that work with the students instead of the imposition of predetermined activities. Moreover, the values themselves, the ways of transmitting the knowledge and the culture of the classroom are conditioned depending on the opinion of the university lecturers about inclusive pedagogy (Nind \& Lewthwaite, 2018).

However, despite having explicit university regulations and a (seemingly) settled educational model, the barriers to the full inclusion of all students are still present. In this regard, Borland \& James (1999) concluded that students with disabilities identified three main barriers to their inclusion in university: (i) physical access barriers, such as infrastructures and spaces; (ii) curricular access barriers, such as methodology and (iii) attitudinal barriers. Specifically, these last barriers have been thoroughly studied by other authors (Hadjikakou \& Hartas, 2008; Moswela \& Mukhopadhyay, 2011; Moriña, López-Gavira \& Molina, 2015), who related the attitudes of university lecturers toward disability to their lack of training, understanding and experience. These studies also provide further evidence of the lack of connection between inclusive regulations in higher education and the experiences of students with disabilities.

It is essential to continue moving towards a model that questions traditional curriculum design and educational practices based on the assumption that all students have the same knowledge, preparation and academic motivation and learn in the same way (Hitch, Macfarlane \& Nihill, 2015). For this reason, a model should be proposed that satisfies and meets the needs of all students (Barrington, 2004; Hockings, 2010) and that 
considers that students should participate in the classroom without differentiation, with the conviction that all, without distinction, contribute to the learning environment (Gale \& Mills, 2013; Black-Hawkins, 2017).

\section{Factors that influence student motivation}

With respect to learning, the cognitive abilities of the students are not the only factors that determine their degree of success or failure in their studies. Arguedas, Daradoumis and Xhafa (2016) stated that emotional and motivational variables play a relevant role in the learning processes. In fact, the Self Determination Theory categorises motivation in a continuum that comprises two opposite states. In the one hand, "amotivation", which is a state of immobilization toward the task. On the other hand, autonomous motivation, which is related to intrinsic goals (health, social relations, personal growth, learning, etc.) and the individual shows high intentions to carry out a specific task (Deci \& Ryan, 2008). Between the two opposite states described, there is a third state: controlled motivation. This neutral state is regulated by external factors and it is related to extrinsic goals (fame, money, recognition, success) (Deci \& Ryan, 2000; Ryan \& Deci, 2000).

However, with regard to the teaching-learning processes, it seems insufficient that students are motivated. Motivation needs to be autonomous in order to have a positive influence on their academic performance. However, acquiring an autonomous motivation does not only depend on the characteristics of the individual. Clearly, this type of motivation is also influenced by the characteristics of the environment (Orsini, Binnie, Wilson \& Villegas, 2017) and by other people, mainly parents and educators (Guay, Ratelle, \& Chanal, 2008).

Finally, in motivational processes, the influence of the environment can make individuals commit to or, on the contrary, disassociate themselves from their intentions to achieve an objective (Deci \& Ryan, 2000). Within the learning contexts, the environment of the classroom is a good predictor of student motivation (Vansteenkiste, Simons, Lens, Sheldon, \& Deci, 2004). If the students find classroom environments in which they feel safe and respected, where they can grow, socialise and be autonomous, their motivation would be higher (Lerdpornkulrat, Koul \& Poondej, 2018). Lecturers and their actions are the key factors that allow the construction of positive learning contexts (Inda-Caro, Maulana, Fernández-García, Peña-Calvo, Rodríguez-Menéndez, \& Helms-Lorenz, 2018).

\section{The influence of teaching on the academic success of the students}

In numerous studies, students with disabilities have stated that one of the main barriers to inclusion in higher education is, in fact, the lecturers (Borland \& James, 1999; Moriña et al., 2015), who do not always generate positive learning contexts. It is fundamental for university lecturers to be sensitive toward diversity. They also need to be trained, and to get to know, value and respect the students, developing all their potential attending to their diversity. This way they can show themselves as active individuals of the classroom, and providing the students with motivation, support and closeness. Hockings 
(2011) added that university lecturers must reflect on what happens inside the classroom, analysing the social relations and hierarchies of students. They should observe situations of discrimination or dominance, in order to control such circumstances and create an inclusive context where everyone can participate and be respected and listened to.

In addition to the classroom environment, the way in which university lecturers present the contents also influences both the way in which their students learn and their motivation toward the different subjects. The most participatory methodologies, i.e., the ones that prioritise the action of the students, seem to have the greatest effect on their motivation (Donche, De Maeyer, Coertjens, Van Daal, \& Van Petegem, 2013). In this regard, studies carried out with engineering students obtained important results. These findings related the perception of self-efficacy to positive emotions and these seemed to improve student motivation (Fritzsche, Schlingensiepen, \& Kordts-Freudinger, 2018). Self-efficacy (a), the feeling of self-control (b), interest (c), the utility of the contents (d), and the establishment of academic and social objectives (e) are, according to Pintrich (2003), the basis of the motivation of university students. This author also proposes a series of strategies that university lecturers can use in the classroom, which are linked to that motivation. Some of these strategies are: to establish clear and reachable objectives, to provide contents and materials that the students find useful and practical, to provide personalised feedback for the development of competences and skills, to foster personal relationships that favour the development of responsibility and the feeling of belonging, and to create learning contexts in which the students feel safe.

\section{Materials and methods}

The results presented in this article are part of a larger research project funded by the Spanish Ministry of Economy and Competitiveness entitled: "Inclusive Pedagogy in the University: Teachers' Narratives" (EDU2016-76587-R).

This project is carried out by a team of researchers from different fields of knowledge (Education Sciences, Economic Sciences, Health Sciences and Experimental Sciences) and from different Spanish universities. It covers a period of four years (2016-2020) and its aim is to know the beliefs, knowledge, designs and actions that university lecturers apply to carry out an inclusive pedagogy.

Specifically, in this study we focused on beliefs and actions. In both dimensions, one of the fundamental aspects was the motivation of all students, in general, and the motivation of students with disabilities, in particular. Therefore, the objectives of this work were: i) to analyse the beliefs of university lecturers with respect to the discouragement of university students, and ii) to know the actions that they carry out to motivate these students. 


\section{Sample}

A total of 16 university lecturers participated in the study, all of them from 4 Spanish universities in which the degree of Physical Activity and Sports Sciences (PASS) was taught. For the recruitment of this sample, different phases were established. Firstly, we contacted the services of attention to students with disabilities of the participating universities. These services, in compliance with the Organic Law of Data Protection (Spanish Government, 1999), gained access through their archives and records to students with disabilities registered in their corresponding university. Later, these students were contacted via email, were given information about the project, and were asked to collaborate. Separately, making use of the "snowball" technique (Dusek, Yurova \& Ruppel, 2015), we asked university lecturers, educational agents and students of these universities to disseminate the project among students with disabilities acquainted to them.

Secondly, we asked the students to propose inclusive university lecturers. In order to make this task easier for them, we provided them with a list of some characteristics and criteria that had to be met by the chosen lecturers: believes in the possibilities of all students; facilitates the learning processes; his/her teaching is active, using different teaching strategies; cares about the learning of the students; is flexible, with a predisposition to help; motivates the students; creates close relationships and favours the interactions between students; makes you feel important, i.e., as part of the classroom; allows students to participate in the classroom and to generate knowledge as a group; and, keeps a horizontal communication with everyone in the classroom.

With the information received, we contacted the university lecturers via email and/ or telephone to ask them to participate in the project. The sample profile is described in Table 1.

\section{Ethical matters}

At the beginning of the interviews, an informed consent document was signed with each participant. This document reported on the project, and ensured that all information would be treated confidentially and anonymously.

Likewise, the participants were offered the possibility to modify any piece of information provided in the interviews, as well as to leave the study whenever they wished. With the aim of guaranteeing the confidentiality mentioned, the data of all the participants became anonymous before initiating the analysis. 
Table 1

Profile of the participants

\begin{tabular}{|c|c|c|c|c|}
\hline $\begin{array}{c}\text { Field of } \\
\text { knowledge }\end{array}$ & & $\begin{array}{l}\text { Didactics } \\
\text { of corporal } \\
\text { expression } \\
\quad \mathrm{N}=12\end{array}$ & $\begin{array}{c}\text { Sport and } \\
\text { physical } \\
\text { education } \\
\mathrm{N}=2\end{array}$ & $\begin{array}{c}\text { Social } \\
\text { psychology } \\
\mathrm{N}=2\end{array}$ \\
\hline \multirow{2}{*}{ Gender } & Men & 44 & 12 & 6 \\
\hline & Women & 31 & - & 6 \\
\hline \multirow{2}{*}{ Age } & $30-40$ years & 75 & 6 & 6 \\
\hline & $41-50$ years & - & 6 & 6 \\
\hline \multirow{4}{*}{ Type of lecturer } & Associate professor & 6 & - & 6 \\
\hline & Adjunct professor & 31 & - & 6 \\
\hline & Lecturer & 37 & 6 & - \\
\hline & Tenured professor & - & 6 & - \\
\hline \multirow{3}{*}{$\begin{array}{l}\text { Teaching expe- } \\
\text { rience }\end{array}$} & $0-10$ years & 31 & - & 6 \\
\hline & $11-20$ years & 37 & 6 & 6 \\
\hline & $21-30$ years & 6 & 6 & - \\
\hline
\end{tabular}

${ }^{*}$ All data are presented in percentages

\section{Data gathering}

This study was carried out from a qualitative approach. For the gathering of data, we designed two semi-structured interview models based on the analytical dimensions of inclusive pedagogy: knowledge, beliefs, designs and actions (Gale \& Mills, 2013; Florian, 2014). The following were some of the questions asked in the interviews: Which do you think are the causes of students becoming discouraged during the course of the subject? And in the case of students with disabilities? Which do you consider to be the keys to get students involved and motivated? Are these keys the same regarding students with disabilities? Which tools or strategies do you usually apply in the classroom when you detect a decrease in the motivation and involvement of your students, with or without disabilities?

All the interviews were carried out by members of the research team. They were conducted face-to-face, except for one case, which was done via phone call. The length of the interviews ranged from 60 to 120 minutes. All the information gathered was recorded and transcribed for later analysis.

\section{Data analysis}

Phase 1. A structural analysis of the obtained data (Riessman, 2008) was carried out in all areas of knowledge covered by the Project. This was done following the proposal of Miles and Huberman (1994). This analysis generated a first proposal of 
categories and codes in an inductive way. During this first phase, some fragments or verbatims of dubious analyses were detected and shared and reviewed by the entire team involved in the project.

Phase 2. The selected analyzed data were related to the area of Physical Activity and Sport Sciences (object of interest of this work). At first, the researchers made a new individual reading of the analyzed data by adjusting the system of categories and codes. Later, a pooling was done to adjust, determine and validate the final categories and codes (table 2).

This analytical process was performed using the computer software MaxQDA 12. This software made it possible to organize and synthesize all the data collected, as well as to establish relationships between them.

Table 2

System of categories and codes for the analysis

\begin{tabular}{|c|c|}
\hline Categories & Codes \\
\hline \multirow{6}{*}{$\begin{array}{l}\text { Beliefs about the causes of discour- } \\
\text { agement }\end{array}$} & Outdated syllabus \\
\hline & Teaching lack of involvement \\
\hline & Low occupational perspectives \\
\hline & Personal issues \\
\hline & False expectations in the degree \\
\hline & Focus of interest on the marks \\
\hline \multirow{5}{*}{$\begin{array}{l}\text { Actions to stimulate student moti- } \\
\text { vation }\end{array}$} & Creation of positive spaces/environments \\
\hline & $\begin{array}{l}\text { Changes in the academic curriculum: updated contents, } \\
\text { innovative methodologies and resources, different } \\
\text { evaluation options }\end{array}$ \\
\hline & Teaching and research interest \\
\hline & Close relationship with the students \\
\hline & Student empowerment \\
\hline
\end{tabular}

\section{Results}

As it has been already commented, this article focuses on the beliefs of professors of the degree in PASS. Specifically, in their opinion on what are the main causes of demotivation of university students and what actions they take to promote motivation. Once the data were analysed, results were grouped into two epigraphs. On the one hand, we present the causes that generated discouragement and, on the other hand, the keys or actions that the participants implemented in the classroom to stimulate the motivation of the students. 


\section{Beliefs about causes that influence student discouragement}

Regarding the causes that influence the discouragement of students, the participants stated that one of the main causes were university curricula. In fact, although many of them could be considered up-to-date, most curricula were outdated and disconnected from each other. Despite syllabus are relatively updated, obsolete subjects and boring content were offered that did not provide students with the necessary tools for further professional development.

P83: "It discourages them because what they find in the real world is not what they see in the classroom. The subjects taught in the degree, at this university, and in each or almost all of the degrees, are usually quite obsolete".

Moreover, the interviewed subjects criticised the lecturers and their pedagogical responsibility. Among the most frequent aspects we found the abusive and constant use of traditional methodologies in university classrooms. They also pointed out that lecturers, in general, did not care about quiet students, and that they did not search for the necessary strategies to catch their attention and improve their motivation. These teaching behaviours were encouraged by the lecturers' evaluation and accreditation system and by the time required for research tasks. In addition, this situation decreased the quality of their teaching tasks and their dedication to these.

P84: "The second (cause) is the fact that the lecturers' accreditation system $(A N E C A)^{1}$ rewards research more than teaching, thus we allocate a lot more time to research and we forget that we are educators. Students realise this because they see that, most of the time, we go to the classroom to hang out and we forget that they are the core of our job".

According to the participants, the low career perspectives of university students for the future constituted another concern and demotivation. It was considered a subject that accompanied and aggravated them from one academic year to the next, facing their university career with a certain apathy and, above all, with an obvious lack of professional projection.

P89: "The fact that they think that when they finish their degree they will be unemployed creates a very discouraging situation. Students do not make real efforts because they think it does not matter what they do since, in the end, they will end up working in a supermarket".

Participants stated that a large number of other causes that discouraged university students were related to personal aspects of the latter. In this sense, university lecturers highlighted different environmental and personal factors related to the students, such as term fatigue, lack of time due to the combination of many subjects, the possibility to work some hours in minimum-wage jobs while studying, and facing different family issues.

National Agency for the Evaluation of the Quality and Accreditation. 
P101: "I believe there are also problems with time pressure. Sometimes they are overwhelmed and discouragement is caused by that: many subjects, practical lectures, family... Besides, many of them have jobs and other responsibilities. They end up overloaded".

According to the university lecturers, another possible cause was related to students' previous expectations. They commented that the students of PASS began the degree motivated mainly by subjects related to sports. Such motivation was affected when they faced subjects of other fields, such as physiology or psychology.

The participants pointed out that these false expectations were related not only to the type of subject but also to the learning requirements of each of them. They claimed that some students had very little knowledge about sports or physical matters, and that they became discouraged when they found themselves overwhelmed by the requirements of the degree. Other students had a good conceptual background and when they started university they became bored and, consequently, their motivation and interest for studying decreased.

P110: "Sports Science students always start out very motivated by sports subjects but the rest of the subjects don't motivate them as much. When they come to the "social psychology" subject on the first day, they come to the classroom on the first day with very low motivation. We are talking about subjects that, not having the word "sport" in the title, displease them from the beginning."

In general, participants highlighted that the students did not consider that the content taught was very useful. This prevented them from enjoying the teaching-learning process, showing special interest or concern for the tests and marks, thus prioritising the evaluation over their learning.

\section{Actions of the lecturers to motivate the students}

The participants pointed out the importance of having an adequate space or infrastructure for the development of both theoretical and practical lectures. Although in most cases these matters were a responsibility of the university, they considered that having comfortable and bright spaces, and classrooms was an influential and necessary aspect for the motivation of students toward learning. Another consideration to stimulate student motivation was related to the academic curriculum. The participants asserted that it was essential to select updated contents that the students could find interesting, useful and attractive. Most important of all, these contents should have a connection with real practice and their future professional development.

P89: "Well, in order to keep the motivation of my students high throughout the course of the subject, which, at least in my experience, is always decreasing, I try to select interesting contents that can be useful to them once they finish their degree"

Among some of the actions that the participants carried out to increase the motivation and interest of their students, they highlighted the importance of teaching practical 
contents. For instance, some of them used current news or examples that were related to the theoretical contents of the subject.

P81: "Sometimes I try to bring current and relevant news in the field of sports and such, in order to increase their motivation. Even if it is not strongly related to the content of the subject at that point, I believe that it can help me stimulate their curiosity".

According to the participants, another key aspect of students' motivation was the teaching methodology. They provided interesting considerations that must be considered. The first of them was related to the importance of taking the interest of the students into account when planning the lectures. They stated that learning should be mainly practical, and that students should learn by doing. They also considered that methodology should be a tool to challenge students to search for solutions based on identified needs. Participants considered that students should become the leader of their own learning, managing their tasks from co-responsibility and commitment.

Another consideration to take into account was related to sessions in the classroom that motivated and entertained the students while they learned. In this sense, some actions that the participants carried out were group assignments in the classroom and programmed visits, with the aim of getting the students to get familiar with experiences related to the subject matter. Likewise, the university lecturers highlighted the importance of having breaks, pauses and recreational breaks throughout the lectures.

P85: "The key to make the students become motivated and involved in the subject is to give them encouraging and entertaining lectures. If the students are bored or consider that the subject is dull, at both the theoretical and practical level, it will be difficult for them to learn"

Apart from the methodology, participants highlighted the importance of using innovative tools in the teaching-learning process. They claimed that Information and Communication Technologies (ICT) could be a good support for the lectures, where the students can make use of them and thus manage their own learning. Likewise, the university lecturers mentioned the importance of continuous evaluation as a motivating strategy. Based on their experience, continuous evaluation had a very positive influence on the motivation of their students, since it considerably reduced the pressure of a final exam.

P101: "I remember a student who had problems to pass other subjects, and she was motivated with my subject, as I applied continuous evaluation. She worked hard and volunteered frequently. I remember that she got the highest mark in the subject and now she is a teacher and does many activities in nature. If she had had a negative experience, it would have been unlikely for her to continue that path".

Another key factor to promote the motivation of the students was the connection between teaching and the line of research of the university lecturers. In this regard, participants considered that being able to teach subjects that were directly related to 
their line of research had a very positive influence on their confidence and control over the contents taught, and how these reached the students.

P81: "I also believe that, since I am lucky to have subjects strongly related to my research and to what I enjoy, my motivation when transmitting the contents is always high throughout the course of the subject, which has a good effect on the students".

Furthermore, participants valued very positively the establishment of close relationships with the students. The fact that they cared about them, their learning, their problems with the subjects, whether they had any personal difficulty that affected their academic career, or even the fact that they knew each of their names, generated an increase in the motivation of the students.

P85: "Besides, when I perceive that, I ask them: "What is it? Why are you not coming to the lectures? Is there anything wrong? What is it that you do not like about the subject?". This is the main resource, and so they tell me, we talk about it, and then I make the necessary adjustments".

Lastly, the participants considered that the role of the university lecturers should go beyond the mere teaching of contents and become a facilitator that empowers students. In fact, according to the participants, the students should stop being mere receptors of information and become the drivers of their own learning.

P89: "We have to empower them... I believe so much in their potential that I try my best to make them see it. I also tell them that they are capable of achieving the objectives of the subject. I always tell them, in order to motivate them, that in the subject about disabilities everything is still under development; i.e., everything that has been done for physical education without disabilities, we have to adapt it all for people with disabilities".

\section{Discussion and Conclusions}

The main findings of this study show that the university lecturers of the degree of PASS considered that there are some factors which influenced the motivation of their students.

Regarding the factors that influenced students' motivation, the participants considered that one of the main causes of discouragement were the syllabus of the degree of PASS. In fact, although they are relatively new, some of these syllabus are usually outdated and comprise subjects that are unpractical and disconnected from the professional reality. A similar result was obtained by Hitch, et al. (2015), who questioned the traditional design of syllabus and homogenous educational practices and highlighted the need to advance toward a model of inclusive pedagogy.

The low professional perspectives of students were another cause of frustration and discouragement mentioned in the study. This is an issue that concerns students almost 
from the beginning of their university life and influences their lack of involvement in their studies. In this regard, other studies have delved into the disparity that exists among the perspectives of students about immediately joining the professional field after finishing their university studies, and the real situation of the current labour market (Islam, Ahmed, Khalifah, Sadiq, \& Faheem, 2015).

Thus, the professional perspective, along with the influence of the family and the professional future, is one of the aspects that affect student motivation the most (Amin, Tani, Eng, Samarasekara \& Huak, 2009). In fact, with respect to the motivational factors, the present study significantly highlights personal issues, especially those related to family problems. This theory is shared by Guay et al., (2008) and Orsini et al. (2017), who pointed out that the characteristics of the environment and the influence of relatives and close people affected students' motivation. In addition to family matters, another frequent barrier for students is to deal with the combination of studying and working, especially subjects with different schedules. Increasingly in Spain, this situation is an obstacle that is becoming one of the main causes of abandonment from university degrees (Freixa, Llanes, \& Venceslao, 2018).

Furthermore, the participants stated that, in some cases, students of PASS enter the degree with certain expectations about the subjects that are not finally met. This results in low satisfaction and poor motivation toward learning. In this sense, we agree with the conclusions of Padilla (2015), who stated that meeting the expectations about academic learning, the methods and the pedagogical techniques used by the lecturers increases the satisfaction of the students with their studies.

Another key aspect of student motivation is related to the academic curriculum. Specifically, one of the fundamental elements is the contents, their utility and their relevance toward the current professional field. In some studies, students highlight the possibility to cooperate in the design of the program of the different subjects. Both students and university lecturers as a positive element can reach a consensus about the contents to be taught (Lubicz-Nawrocka \& Bunting, 2019). Thus, the subject matter can be more significant and more closely related to the interests and needs of the students. In the same line, the participants of the present study also mentioned the importance of approaching the teaching-learning process with a methodology targeted to action and practice. This methodology promotes the participation and leadership of the students and challenges them to search for solutions (Donche et al., 2013; Fritzsche et al., 2018).

Other elements that foster student motivation are the use of different methodological techniques. In this sense, the university lecturers participating in this study suggest dynamizing the teaching process. Some of the proposals include visits that allow the students to know practical experiences and connect them with the professional reality, and the use of innovative resources and tools, such as ICT (Pintrich, 2003). Likewise, it is essential to make use of the different types of assessment (Lubicz-Nawrocka \& Bunting, 
2019), especially formative and continuous, since they are presented as the most innovative types of evaluation for students (Hortigüela-Alcalá, Palacios-Picos \& López-Pastor, 2019).

Regarding the university lecturers, a fundamental aspect for improving motivation among students is the relationship between the educational profile and the researching profile. In this sense, the participants pointed out that their experience in teaching certain subjects or the connection between the subject matter taught and the research lines that they worked on had a very positive impact on their teaching practice. Students enjoy the subject more when the university lecturers are active researchers in the topic they teach (Ramsden, 2000). In a study carried out at the University of Edinburgh, the students highlighted that the excellence of the university lecturers was determined, among other aspects, by their ability to show their passion for a topic and their interest and enthusiasm for teaching their students (Lubicz-Nawrocka \& Bunting, 2019).

Another important aspect is that university lecturers must establish close relationships with their students. They might show them that they care about how they assimilate the subject and about their difficulties throughout their learning. This has also been identified by other authors (Guay, et al., 2008; Hockings, 2011; Naz \& Murad, 2017). This approach is also shared by Potee (2002) and Falout, Elwood, and Hood (2009), who found that a reachable and friendly attitude in university lecturers could positively or negatively affect the motivation and learning of the students.

In addition, lecturers proposed to establish challenges and actions according to the students' potential in order to promote their empowerment. In this regard, Donche et al. (2013) showed that some students were stimulated by the fact that their university lecturers provided them with learning environments that granted more freedom and encouraged their autonomy and self-regulation.

After the analysis carried out, we can conclude that the results of our study complement the theories of inclusive pedagogy. The participating university professors considered that the students' motivation variables influenced their learning processes. Moreover, we can assert that the participants did not find any differences between students with disabilities and those without disabilities regarding the causes of their discouragement, and that they did not carry out differentiated activities for the former. In this sense, we agree with in whose study it is stated that the principles of inclusive pedagogy imply attending to all students, generalizing participation in the classroom, without differentiation (Black-Hawkins, 2017). This shows that these university lecturers are sensitive toward the proposals of inclusive pedagogy (O'Shea, et al., 2016).

Another interesting aspect to highlight is that all students, whether they have a disability or not, offer value to the learning environment, in coincidence with the principles of inclusive pedagogy advocated by authors such as Gale and Mills (2013).

A final aspect to be highlighted is that the inclusive practices carried out by the teaching staff have made it possible to satisfy and meet the needs of all students. This is in line with other studies that claim that teaching practices and methods linked to inclusive 
pedagogy generate meaningful, useful and accessible learning for all (Barrington, 2004; Hockings, 2010).

Concerning the most innovative aspects of our study, we can highlight that the participants were the ones who showed their beliefs and knowledge regarding when and how the students became discouraged. Apart from describing these aspects, the participants described the actions they carried out to restore the motivation of their students whenever they detected a decrease in it, becoming an example to other university lecturers. Lastly, the study was contextualised in university lecturers of the degree of PASS, which makes it a pioneer work in this field of knowledge.

\section{Limitation and further perspectives of research}

The main limitation of the study is the size of the sample. It would have been desirable to have in the study a larger number of participants from the field of physical activity and sport sciences. This would have increased the value of the article. However, when using student recommendations as selection criteria, we must take into account the small number of students with disabilities who are registered in this area (Universia Foundation, 2016).

With regard to the presentation of new research perspectives, it would be interesting to address the study of other categories contemplated in the Project, such as the level of knowledge of teachers on inclusive education, or the design of subjects to be inclusive. We also recommend future research on the development and evaluation of training programmes. These programmes could aim to develop inclusive education and strengthen the teaching skills of teachers to motivate, challenge and empower students.

\section{Conflict of interests}

No conflicts of interest have been declared.

\section{Funding details}

The results of this study are located within the framework of a broader research project (Inclusive Pedagogy at the University: Faculty Narratives ref. EDU2016-76587-R). This study was reviewed and approved by the ethics committee of the Spanish Ministry of the Economy and Competitiveness. 


\section{References}

Ainscow, M., Dyson, A., Goldrick, S. \& West, M. (2013). Promoviendo la equidad en educación. Revista de Investigación en Educación, 3, 44-56. http://reined.webs.uvigo.es/ojs/index.php/ reined/article/view/732

Amin, Z., Tani, M., Eng, K. H., Samarasekara, D., \& Huak, C. Y. (2009). Motivation, Study Habits, and Expectations of Medical Students in Singapore. Medical Teacher, 31(12), Article e560-e569. doi: 10.3109/01421590903193554

Arguedas, M., Daradoumis, T., \& Xhafa, F. (2016). Analyzing How Emotion Awareness Influences Students' Motivation, Engagement, Self-Regulation and Learning Outcome. Educational Technology \& Society, 19(2), 87-103. https://eric.ed.gov/?id=EJ1097275

Barrington, E. (2004). Teaching to Student Diversity in Higher Education: How Multiple Intelligence Theory can help. Teaching in Higher Education, 9(4), 421-434. doi: $10.1080 / 1356251042000252363$

Black-Hawkins, K. (2017). Understanding Inclusive Pedagogy. Learning with and from Teachers. En V. Plows \& B. Whitburn (eds.). Inclusive Education. Making Sense of Everyday Practice. (pp.13-28). Rotterdam: SensePublishers. doi: 10.1007/978-94-6300-866-215

Borland, J., \& James, S. (1999). The Learning Experience of Students with Disabilities in Higher Education. A Case Study of a UK University. Disability \& Society, 14(1), 85-101. doi: 10.1080/09687599926398

Deci, E. L., \& Ryan, R. M. (2000). The 'What' and 'Why' of Goal Pursuits: Human Needs and the Self-Determination of Behavior. Psychological Inquiry. International Journal for the Advancement of Psychological Theory, 11(4), 227-268. doi:10.1207/S15327965PLI1104_01

Deci, E. L., \& Ryan, R. M. (2008). Self-Determination Theory: A Macrotheory of Human Motivation, Development, and Health. Canadian Psychology, 49(3), 182-185. doi: 10.1037/ a0012801

Donche, V., De Maeyer, S., Coertjens, L., Van Daal, T., \& Van Petegem, P. (2013). Differential Use of Learning Strategies in First-Year Higher Education: The Impact of Personality, Academic Motivation, and Teaching Strategies. British Journal of Educational Psychology, 83, 238-251. doi:10.1111/bjep.12016

Dusek, G. A, Yurova Y. V, Ruppel C. P. (2015). Using Social Media and Targeted Snowball Sampling to Survey a Hard-to-Reach Population: A case study. International Journal of Doctoral Studies, 10, 279-299. doi: 10.28945/2296

Falout, J., Elwood, J., \& Hood, M. (2009). Demotivation: Affective States and Learning Outcomes. System, 37, 403-417. doi:10.1016/j.system.2009.03.004

Freixa, M., Llanes, J., \& Venceslao, M. (2018). El abandono en el recorrido formativo del estudiante de ADE de la Universidad de Barcelona. Revista de Investigación Educativa, 36(1), 185-202. doi: 10.6018/rie.36.1.278971

Florian, L. (2014). What counts as evidence of inclusive education? European Journal of Special Needs Education, 29(3), 286-294._doi: 10.1080/08856257.2014.933551 
Florian, L., \& Black-Hawkins, K. (2011). Exploring Inclusive Pedagogy. British Educational Research Journal, 37(5), 813-828. doi: 10.1080/01411926.2010.501096

Fritzsche, E. S., Schlingensiepen, J., \& Kordts-Freudinger, R. (April, 2018). Study Motivation and Academic Emotions in Engineering Students. A Case Study in German Higher Education. IEEE Global Engineering Education Conference EDUCON. Santa Cruz de Tenerife, Canary Islands, Spain. https://ieeexplore.ieee.org/abstract/document/8363280

Fundación Universia. (2016). Universidad y discapacidad. III Estudio sobre el grado de inclusión del sistema universitario español respecto de la realidad de la discapacidad. Retrieved from Fundación Universia website: https://www.fundacionuniversia.net/wpcontent/ uploads/2017/02/Fundacion_IIIEstudio_digital_accesible.pdf

Gale, T., \& Mills, C. (2013). Creating Spaces in Higher Education for Marginalized Australians: Principles for Socially Inclusive Pedagogies. Enhancing Learning in the Social Sciences, 5(2), 7-19. doi: 10.11120/elss.2013.00008

Guay, F., Ratelle, C. F. \& Chanal, J. (2008). Optimal Learning in Optimal Contexts: The Role of Self-Determination in Education. Canadian Psychology, 49(3), 233-240. doi: 10.1037/a0012758

Gobierno de España (1999). Ley Orgánica de Protección de Datos (BOE-A-1999-23750). Retrieved from: https://www.boe.es/eli/es/lo/1999/12/13/15/con

Gobierno de España (2006). Ley Orgánica de Educación. (BOE-A-2006-7899). Retrieved from: https://www.boe.es/buscar/pdf/2006/BOE-A-2006-7899-consolidado.pdf

Gobierno de España. (2007). Ley Orgánica para Universidades (04/2007). Retrieved from: https:// www.boe.es/boe/dias/2007/04/13/pdfs/A16241-16260.pdf

Gobierno de España (2013). Ley Orgánica para la mejora de la calidad educativa. (BOE-A-2013-12886). Retrieved from: https://www.boe.es/buscar/pdf/2013/BOE-A-201312886-consolidado.pdf

Hadjikakou, K., \& Hartas, D. (2008). Higher Education Provision for Students with Disabilities in Cyprus. Higher Education, 55(1), 103-119. Retrieved from: http://wrap.warwick.ac.uk/573/ Hitch, D., Macfarlane, S., \& Nihill, C. (2015). Inclusive Pedagogy in Australian Universities: A Review of Current Policies and Professional Development Activities. The International Journal of the First Year in Higher Education, 6(1), 135-145. doi: 10.5204/intjfyhe.v6i1.254

Hockings, C., Cooke, S., \& Bowl, M. (2007). Academic Engagement' within a Widening Participation Context-a 3D analysis, Teaching in Higher Education, 12(5-6), 721-733. doi: 10.1080/13562510701596323

Hockings, C. (2010). Inclusive Learning and Teaching in Higher Education: A Synthesis of Research. York, UK: The Higher Education Academy.

Hockings, C. (2011). Hearing Voices, Creating Spaces: the Craft of the 'Artisan Teacher' in a Mass Higher Education System. Critical Studies in Education, 52(2), 191-205. doi: 10.1080/17508487.2011.572831

Hortigüela, D. Palacios, A., \& López, V. (2019). The Impact of Formative and Shared or Coassessment on the Acquisition of Transversal Competences in Higher Education. Assessment \& Evaluation in Higher Education, 44(6), 933-945. doi: 10.1080/02602938.2018.1530341 
Inda-Caro, M., Maulana, R., Fernández-García, C. M., Peña-Calvo, J. V., Rodríguez-Menéndez, M. C., \& Helms-Lorenz, M. (2018). Validating a Model of Effective Teaching Behaviour and Student Engagement: Perspectives from Spanish Students. Learning Environments Research, 1-23. doi: 10.1007/s10984-018-9275-z

Islam, T., Ahmed, I., Khalifah, Z., Sadiq, M., \& Faheem, M. A. (2015). Graduates' Expectation Gap: the Role of Employers and Higher Learning Institutes. Journal of Applied Research in Higher Education, 7(2), 372-384. doi: 10.1108/JARHE-05-2014-0056

Jucevičienè, P., Vizgirdaitè, J. \& Alexander, H. (2018). Accessibility and Inclusion in Higher Education: Implamenting International Imperatives in National and Institutional Contexts. Pedagogika, 130 (2), 46-63. doi: 10.15823/p.2018.21

Lerdpornkulrat, T., Koul, R., \& Poondej, C. (2018). Relationship between Perceptions of Classroom Climate and Institutional Goal Structures and Student Motivation, Engagement and Intention to Persist in College. Journal of Further and Higher Education, 42(1), 102-115. doi: 10.1080/0309877X.2016.1206855

Lubicz-Nawrocka, T., \& Bunting, K. (2019). Student Perceptions of Teaching Excellence: an Analysis of Student-led Teaching Award Nomination Data. Teaching in Higher Education, 24(1), 63-80. doi: 10.1080/13562517.2018.1461620

Miles, M. B \& Huberman, A.M. (1994). Qualitative Data Analysis: An Expanded Sourcebook $\left(2^{\text {nd }}\right.$ Ed). Thousand Oaks, CA: Sage Publications.

Moriña, A., López-Gavira, R., \& Molina, V. M. (2015). Students with Disabilities in Higher Education: a Biographical Narrative Approach to the Role of Lecturers. Higher Education Research \& Development, 34(1), 147-159. doi:10.1080/07294360.2014.934329

Moswela, E., \& Mukhopadhyay, S. (2011). Asking for too Much? The Voices of Students with Disabilities in Botswana. Disability \& Society, 26(3), 307-319. doi: 10.1080/09687599.2011.560414

Muthukrishna, N. (2002). Inclusive Education in a Rural Context in South Africa: Emerging Polity and Practices. International Journal of Special Education, 17(1), 1-10. https://link.springer. com/article/10.1007/BF03173414

Naz, F., \& Murad, H. S. (2017). Innovative Teaching has a Positive Impact on the Performance of Diverse Students. Special Collection-Student Diversity, 7(4) 1-8. doi: 10.1177/2158244017734022

Nind, M., \& Lewthwaite, S. (2018). Hard to Teach: Inclusive Pedagogy in Social Science Research Methods education. International Journal of Inclusive Education, 22(1), 74-88. doi: 10.1080/13603116.2017.1355413

Orsini, C., Binnie, V., Wilson, S., \& Villegas, M. J. (2017). Learning Climate and Feedback as Predictors of Dental Students' Self-determined Motivation: The Mediating Role of Basic Psychological Needs Satisfaction. European Journal of Dental Education, 22, 228-236. doi: 10.1111/eje.12277

O’Shea, S., Lysaght, P., Roberts, J. \& Harwood, V. (2016). Shifting the Blame in Higher Education Social Inclusion and Deficit Discourses. Higher Education Research and Development, 35(2), 322-336. doi: 10.1080/07294360.2015.1087388 
Padilla, J. (2015). Expectativas, satisfacción y rendimiento académico en alumnado universitario. Revista de Psicología y Educación, 10(1), 11-32.

Pintrich, P. R. (2003). A Motivational Science Perspective on the Role of Student Motivation in Learning and Teaching Contexts. Journal of Educational Psychology, 95(4), 667-686. doi: 10.1037/0022-0663.95.4.667

Potee, N. (2002). Teacher Immediacy and Student Motivation. In D.M. McInerney \& S. Van Etten (Eds.), Sociocultural Influences on Motivation and Learning: An Historical Perspective (pp. 207-223). Greenwich, Connecticut: Information Age Publishing.

Ramsden, P. (2000). Strategic Management of Teaching and Learning. 8th International Improving Student Learning Symposium. UMIST, Manchester, UK.

Riessman, C. K. (2008). Narrative Methods for the Human Sciences. Sage Publications.

Ryan, R. M., \& Deci, E. L. (2000). Self-determination theory and the facilitation of intrinsic motivation, social development, and well-being. American Psychologist, 55(1), 68-78. doi: 10.1037/0003-066X.55.1.68

Stainback, S. \& Stainback, W. (1999). Aulas inclusivas. Narcea.

Tant, M., \& Watelain, E. (2016). Forty Years Later, a Systematic Literature Review on Inclusion in Physical Education (1975-2015): A teacher perspective. Educational Research Review, 19, 1-17. doi: 10.1016/j.edurev.2016.04.002

UNESCO (1994). Salamanca Statement and Framework for on Special Needs Education: Access and quality. Paris: UNESCO. http://www.unesco.org/education/pdf/SALAMA_E.PDF

Vansteenkiste, M., Simons, J., Lens, W., Sheldon, K. M., \& Deci, E. L. (2004). Motivating Learning, Performance, and Persistence: The Synergistic Effects of Intrinsic Goal Contents and Autonomy-Supportive Contexts. Journal of Personality and Social Psychology, 87(2), 246-260. doi: 10.1037/0022-3514.87.2.246

Vlachou, A. (2004). Education and Inclusive Policy-Making: Implications for Research and Practice. International Journal of Inclusive Education, 8(1), 3-21. doi: 10.1080/1360311032000139449

Whitburn, B., \& Plows, V. (2017). Making Sense of Everyday Practice: By Whom, for Whom, for What? In V. Plows \& B. Whitburn (eds.), Inclusive education. Making sense of everyday practice. SensePublishers. doi: 10.1007/978-94-6300-866-215 


\title{
Sporto mokslo ir fizinio aktyvumo universiteto dèstytojų issitikinimai ir veiksmai, susiję su studentų mokymosi motyvacija
}

\author{
Noelia Melero Aguilar ${ }^{1}$, Ana Domenech Vidal' ${ }^{2}$, Ruth Cabeza-Ruiz ${ }^{3}$ \\ 1 Noelia Melero Aguilar, Sevilijos universitetas, Ugdymo ir socialinės pedagogikos teorijos ir istorijos katedra, \\ C / Pirotecnia s/n, ES-41013, Sevillija, Ispanija, nmelero@us.es \\ 2 Ana Domenech Vidal, Kadiso universitetas, Didaktikos katedra, C/ Saharaui respublika, 12, ES-11519, Puerto Real, \\ Kadisas, Ispanija, ana.domenech@gm.uca.es \\ 3 Ruth Cabeza-Ruiz, Sevilijos universitetas, Žmogaus galimybių ir sporto katedra, C/ Pirotecnia s/n, ES-41013, \\ Sevilija, Ispanija, ruthcr@us.es
}

\section{Santrauka}

Šis tyrimas, patvirtintas Ispanijos ekonomikos ir konkurencingumo ministerijos, yra atliekamas skirtinguose Ispanijos universitetuose kaip platesnio vykdomo tyrimo projekto dalis (vykdoma inkliuzinė pedagogika, renkami fakultetų narių pasakojimai). Ši projektą vykdo įvairių sričių (švietimo, ekonomikos, sveikatos ir eksperimentinių mokslų) ir skirtingų Ispanijos universitetų tyrinètojų komanda. Tyrimo tikslas - išanalizuoti Sporto mokslo ir fizinio aktyvumo universiteto dėstytojų nuostatas apie pagrindines universitetų studentų, o ypač neigalių studentų, mokymosi motyvavimo priežastis. Taip pat tiriami veiksmai, kuriuos dėstytojai atlieka savo klasėse studentų motyvacijai skatinti. Buvo atlikta 16 pusiau struktūruotų interviu su 16 dėstytojų. Vèliau duomenys buvo analizuojami naudojant kategorijų ir indukcinių kodų sistemą. Rezultatai rodo, kad kai kurių studentų demotyvacijos priežastys yra susijusios su pasenusiomis mokymo programomis ar klaidingais karjeros lūkesčiais. Tyrime dalyvaujantys dèstytojai, atsižvelgdami ị šiuos demotyvuojančius veiksnius, naudojasi ịvairiomis strategijomis, tokiomis kaip mokymosi erdvės ir palankios aplinkos kūrimas, mokymo programos rengimas ir studentų ịgalinimas. Suformuotos išvados atskleidžia, kad dèstytojai, dirbdami pagal inkliuzinio mokymo programą, vertina studentus, iggalina pozityvią mokymosi aplinką ir atsižvelgia ị visų studentų interesus bei poreikius.

Esminiai žodžiai: inkliuzinė pedagogika, sporto mokslas, fizinis aktyvumas, universiteto dèstytojai, motyvacija. 